\title{
Differential Responses of Commercial Tomato Rootstocks to Branched Broomrape
}

\author{
Rida Draie $^{1,2, *}$ \\ ${ }^{1}$ Faculty of Agriculture, Idleb University, Syria \\ ${ }^{2}$ Research work carried out at LBPV Laboratory, Nantes University, France \\ *Corresponding author: ridadraie@hotmail.com
}

\begin{abstract}
Gravely infestation of tomato fields by Broomrape (Phelipanche ramosa) is growing in the Mediterranean basin. Completely devoid of chlorophyll, the root-parasite is entirely dependent on the host-derives and successively competes with the sink organs of infected plants. No efficient and economic control means has been found. Tomato grafting on resistant rootstocks is a very efficient solution for soil parasites control. The selected tomato rootstocks for their resistance to the soil parasites could be also a source of resistance to the Broomrape. In this work, we screen different commercial tomato rootstock genotypes for their resistance to Phelipanche ramosa. In the greenhouse conditions, we show that rootstocks are different in the degree of susceptibility to Broomrape. Attachment number, emergence number, and fresh matter of parasitic broomrapes are affected by rootstock genotype. A significant impact of the parasitism onto the dry weight of all infected tomato rootstocks with variable degree is observed. Energy, Groundforce and Eldorado which have less of attachment number and emergence number successively appear interesting for our objective.
\end{abstract}

Keywords: commercial rootstocks, tomato, screening, resistance, tolerance, branched broomrape

Cite This Article: Rida Draie, "Differential Responses of Commercial Tomato Rootstocks to Branched Broomrape.” Research in Plant Sciences, vol. 5, no. 1 (2017): 15-25. doi: 10.12691/plant-5-1-3.

\section{Introduction}

Tomato (Solanum lycopersicum L.) is an important vegetable crop at mondial level. Infestation of tomato fields by branched and Egyptian broomrapes (Phelipanche ramosa, $P$. aegyptiaca $L$., respectively) is growing in the arid and semi-arid environments, especially in the Mediterranean basin. Tomato is the most affected crop being the prominent host of this parasite. Yield losses in tomato fields can reach $25 \%$ to $75 \%$ in heavy-infested fields [1,2,3]. Recently, Mauromicale et al., [4] showed that the broomrape causes a significant reduction of tomato photosynthetic capacity, thus generating a significant loss of their aerial organs biomass. The danger of this parasite comes from the long viability of its tiny seeds $(0,2-0,3 \mathrm{~mm}$ and $3 \mu \mathrm{g})$ in the ground, which exceed at least the ten years, and of its very high rate of multiplication (100000 seeds plant ${ }^{-1}$ ), [5]. Moreover, the majority of the damage on the host is caused during the underground growth of the parasite and no practical methods to control it effectively [6].

Broomrapes are obligate parasitic flowering plants which depend entirely on their host plants for water and nutritional requirements [7]. After connecting to the host root vascular system through a haustorium acting as a bridge for water and nutrient uptake, the parasite first undergoes a subterranean growth resulting in tubercle and subterranean stem development. This is followed by emerging above soil, flowering and producing a large number of seeds. Broomrape seed germination starts in response to stimulants secreted from roots of host plants $[8,9]$. However seeds respond to stimuli only after being exposed to water and suitable temperatures for several days, corresponding to the conditioning period [10].

Some integrated methods based on cultural, biological, physical, and chemical means are proposed to control broomrape in processing tomato [11,12]. Indeed good results were obtained by solarization $[13,14]$ and by the integration of peas, soybean, sorghum or maize in the crop rotation as trap crops as they stimulate Phelipanche seed germination but are not infected, then reducing the Phelipanche seed bank of the soil. Biocontrol with either Phelipanche-pathogenic Fusarium strains or mycoherbicides is also promising $[15,16]$. Nevertheless the most effective method to control the parasitic weed Phelipanche in processing tomato is to apply sulfonylurea herbicides on tomato foliage and by injection through the drip irrigation system $[17,18]$. In parallel, there is an increasing market for organically grown tomatoes, where the use of chemical pesticides is not an option [19].

The genetic approach getting resistance in tomato is unsuccessful until now as the molecular components of the response of tomato to broomrape is poorly studied [20] and as no strong response or immunity against broomrape was observed from the large-scale screenings in tomato germplasm [21-26], all the screened lines being susceptible to varying degrees. Indeed, Kasrawi and Abu-Irmaileh, [25] and Qasem and Kasrawi [26] underlined the good level of resistance to $P$. ramosa for accessions LA1380, LA1599, LA1581 and LA1478 of S. pimpinellifolium This 
resistance results in a limited number of broomrapes emerged by tomato plant. Recently, El-Halmouch et al., [27] characterized the strong resistance to $P$. aegyptiaca of the wild tomato $L$. pennellii $L A 716$. This resistance is multifactorial since it rests mainly on a very weak stimulative activity of the root exudates with respect to the parasite germination, but also on the induction of necroses broomrapes fixed by the installation of a layer of encapsulation around the zone of penetration of the parasite, on parietal reinforcements by lignification, and on the occlusion of xylemian vessels. Existence of such inhibitors compounds in root exudates of resistant plants was also suggested by Whitney, [28] and Whitney and Carsten, [29].

The research of resistance or tolerance in tomato remains a priority. Because genetic variability available at cultivated tomato is very limited, the search for sources of resistance to the broomrape at the wild species, which have a genetic diversity 10 times higher, can be an interesting solution [30]. The selection for resistance to the soil diseases and parasites currently leads to hybrids F1, carrying of dominant genes, making it possible to control several pathogenic. These hybrids are used as rootstocks of tomato [31]. Therefore, we hypothesized that tomato grafting, on resistant rootstocks, could improve resistance or tolerance to broomrape like they do it against some other soil parasites. Indeed vegetables grafting is obligatory in the biologic cultures [32], since it is an interesting alternative to chemicals such as methyl bromide while making it possible to bring a good resistance to many diseases and parasites of the soil [19,33,34,35].

In contrast the behavior of those rootstocks to the root-parasitic plant Phelipanche is unknown. The present work aimed to screen the most popular commercial of tomato rootstocks against Phelipanche ramosa under artificial infestation in controlled environmental conditions, revealing their respective degree of susceptibility and tolerance to the parasitic weed. Susceptibility was evaluated using the total number and dry weight (DW) of attached broomrapes per host plant and the number of emerged broomrape shoots per host plant as indicators. Tolerance was estimated according to the impact of parasitism on DW biomass of the host plant. The opportunity to use tomato rootstocks as source of resistance against $P$. ramosa is discussed.

\section{Materials and Methods}

\subsection{Plant Materials}

Twelve popular commercial tomato rootstocks (Beaufort, Maxifort, Heman, 42851, 43965, Brigeor, Integro, Energy, Body, Robusta, Groundforce and Eldorado), which were selected for their resistance to soil diseases and parasites, and one research rootstock La4135 (Table 1), were tested for their susceptibility to branched broomrape (Phelipanche ramosa). The choice of the rootstock La4135 (S. lycopersicum cv. VF36 $\times$ S. pennellii LA0716) is explained by the fact that $S$. pennellii presented a partial resistance to the egyptian broomrape [36]. The broomrape seeds were collected from flowering spikes in infested rapeseed fields (Pathovar C, Saint-Martin-de-Fraigneau, Vendée, France, 2005). Once cleaned, the seeds were stored in darkness at $25^{\circ} \mathrm{C}$ until use.

\subsection{Germination Tests}

The ability of broomrape seeds to germinate was evaluated in the presence of the synthetic germination stimulant $\mathrm{GR}_{24}$. P. ramosa seeds (5 $\mathrm{mg} \mathrm{DW}$ ) were sterilized for 5 min in sodium hypochlorite (3.61\%) and rinsed three times with sterile distilled water. The sterilized seeds were conditioned at $25^{\circ} \mathrm{C}$ for 1 week on filter paper moistened with $5 \mathrm{~mL}$ of sterile distilled water in a Petri dish $(\varnothing 9 \mathrm{~cm})$ covered with aluminum foil. Germination was then stimulated by addition of $1 \mathrm{~mL}$ of $\mathrm{GR}_{24}$ (1 ppm), a synthetic strigol analogue (natural stimulant). Four days after the conditioning period, seed germination rate was estimated by adding of $1 \mathrm{ml}$ of pansso red, and then the germinated seeds were counted under a binocular microscope (Olympus SZX10).

Table 1. Principal characteristics and resistances of the tomato rootstocks, used to determine their degree of susceptibility to the branched broomrape; TMV: Tomato Mosaic Virus; For: Fusarium oxysporum Radicis-lycopersici (crown rot); Fol: Fusarium oxysporum lycopersici races 0 and 1 (1 and 2); CF: Cladosporium fulvum; CR: Corky Root (Pyrenochaeta lycopersici); V: Verticillium sp.; N: Nematodes: the most known species (Meloidogyne); St: Stemphyllium; Rs: Bacteria (Ralstonia Solanacearum); HR: High Resistance; IR: Intermediate resistance

\begin{tabular}{|c|c|c|c|}
\hline Rootstock & Society & Hybrid Identity & Resistance Codes \\
\hline Groundforce & Sakata & S. lycopersicum $\times$ Solanum $s p$. & HR : TMV, V, Fol, N, CR, Rs \\
\hline Integro & Vilmorin & S. lycopersicum $\times$ S. hirsutum & HR : TMV, V, Fol, N, CR, For \\
\hline Energy & Vilmorin & S. lycopersicum $\times$ S. lycopersicum & HR : TMV, Fol, For ; IR : V, (N, CR) \\
\hline Beaufort & De Ruiter Seeds & S. lycopersicum $\times$ S. habrochaites & HR : TMV, CR, N, V, Fol, For, \\
\hline Maxifort & De Ruiter Seeds & S. lycopersicum $\times$ S. habrochaites & HR : TMV, V, Fol, For, CR, N \\
\hline Body & Siminis & S. lycopersicum $\times$ S. hirsutum & HR : TMV, V, Fol, For, CF, CR, N, St \\
\hline Robusta & Siminis & S. lycopersicum $\times$ S. lycopersicum & HR : TMV, V, Fol, For, CF, CR, N \\
\hline Heman & Syngenta Seeds & S. lycopersicum $\times$ S. habrochaites & HR : For, Fol, TMV, V, CF ; IR : N, CR \\
\hline 42851 & Syngenta Seeds & S. lycopersicum $\times$ S. habrochaites & HR : For, Fol, TMV, V, CF ; IR : N, CR \\
\hline 43965 & Syngenta Seeds & S. lycopersicum $\times$ S. habrochaites & HR : For, Fol, TMV, V, CF ; IR : N, CR \\
\hline Eldorado & Enzazaden & S. lycopersicum $\times$ Solanum $s p$. & HR : TMV, CF, CR, V, Fol, For, N \\
\hline Brigeor & Gautier Seeds & S. lycopersicum $\times$ Solanum $s p$. & HR : TMV, Fol:2, For, V, N \\
\hline La4135 & TGRC & S. lycopersicum cv. VF36 × S. pennellii LA0716 & Not available \\
\hline
\end{tabular}




\subsection{Interactions Tomato-Broomrape in Pot (Screenings in Greenhouse)}

$P$. ramosa seeds $\left(10 \mathrm{mg} \mathrm{L^{-1 }}\right.$ of soil) were mixed homogeneously with a 1:1:1 peat-sand-clay mixture in a pot of 3L (about 10000 seeds pot $^{-1}$ ). Cultures were managed in greenhouse conditions. Ten infested and ten non infested pots were equipped per tomato rootstock $(n=10)$. The soil infestation by $P$. ramosa seeds then the mixture homogenization were carried out manually in each pot. The pots were watered and protected from the light with a black plastic film then maintained in this conditions for 1 week at $20-25^{\circ} \mathrm{C}$ (day-night temperature). Following Phelipanche seed conditioning, three tomato rootstocks seeds were sown directly into each pot. The plants grew under a photoperiod of $16 \mathrm{~h}\left(300 \mu \mathrm{mol} \mathrm{m} \mathrm{m}^{-2} \mathrm{~s}^{-1}\right.$ $\mathrm{PAR}$ ) and at $20-25^{\circ} \mathrm{C}$ and $15-18^{\circ} \mathrm{C}$ (day-night temperature). Three weeks later seedlings were thinned to one per pot. The tomato rootstocks were sprinkled one time per week with a sterile solution of $50 \%$ Coïc neutrophile nutrient solution [37]. The tomato plants were addressed, propped and the greedy removed progressively with their development. Two independent culture campaigns were performed. The first one was aimed to screen the twelve commercial and La4135 tomato rootstocks. Note that the rootstocks Integro and Robusta were integrated into the two culture campaigns, then serving as controls. The second screening campaign was duplicated the first campaign. Nevertheless, from the results of the first campaign, the less interesting rootstocks were excluded from the second culture campaign.

\subsection{Collecting of Experimental Data}

Twelve weeks after sowing, tomato plants were gently uprooted from the soil. The broomrapes (attached and emerged) are collected, washed carefully then classified according to their stage of development [38]. stage 1: attachment of the germinated broomrapes to the host roots; stage 2: tubercle formation; stage 3: appearance of adventive roots on the parasite tubercle; stage 4: stem formation and development; stage 5: broomrape emerged in flowers and fructification; stage 6: faded flowers mature capsules (Figure 1). The degree of rootstocks susceptibility was evaluated by the total number of fixed broomrapes per plant [39], by the number of emerged broomrapes per plant $[26,40,41,42,43,44]$, and by the total dry biomass of broomrapes per plant [36]. In parallel, the impact of parasitism on the rootstocks was estimated by the measurement of the fresh and dry aerial parts and roots biomass of the infected and healthy plants. The biomasses were measured after drying of the samples at $80^{\circ} \mathrm{C}$ for $72 \mathrm{~h}$ $[36,45]$.

\subsection{Statistical Analysis}

Statistical analyses were performed using the SigmaStat software (version 3,5). The comparisons of average were based on the test of Student Newman Keuls (ANOVA, SNK, $\mathrm{P} \leq 0,005, \mathrm{n}=10$ ).
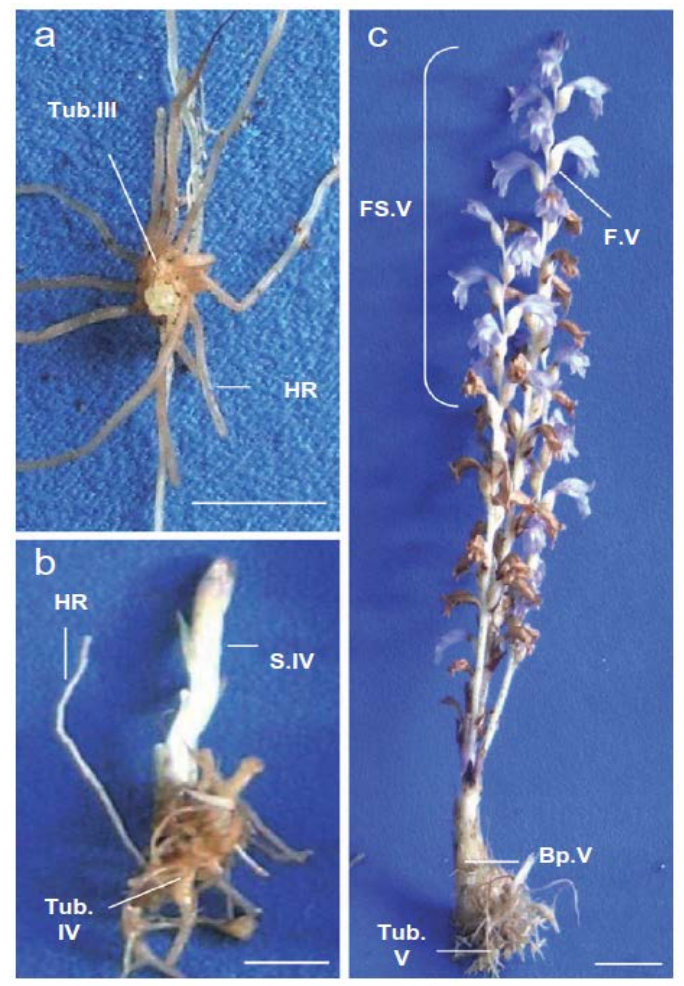

Figure 1. Developmental stages in Phelipanche ramosa parasitizing tomato plants: (a) stage III, growing tubercle (Tub.III); (b) stage IV, tubercle (Tub.IV) bearing the growing subterranean shoot (S.IV); (c) stage V, tubercle (Tub.V) bearing the emerged flowering shoot. Apical part of the flowering shoot is growing (FS.V) and bears fruits containing developing seeds (F.V). Basal part (Bp.V) does not bear flowers and is larger and more fibrous than the flowering shoot. HR, host roots (tomato). Bar, 1 cm. [46]

\section{Results}

\subsection{Germination Tests}

After 7-day conditioning, all the tested $\mathrm{GR}_{24}$ concentrations from 0.1 to $10 \mathrm{mg} \mathrm{L}^{-1}$ triggered high germination rates, up to the optimal value of $99 \%$ with $\mathrm{GR}_{24} 1 \mathrm{ppm}$ (Table 2). This preliminary test was essential to prove the good ability of the broomrape seeds to germinate in the presence of germination stimulants. Thus, this seed set could be used for the screening of the tomato rootstocks in greenhouse.

Table 2. Results of germination test of broomrape seeds after 1 week of preconditioning then treatment for 4 days with GR24. The values carrying the same letter are not significantly different (ANOVA, SNK, $\mathbf{P} \leq \mathbf{0 , 0 5}, \mathrm{n}=3$ )

\begin{tabular}{|c|c|}
\hline $\begin{array}{c}\text { GR24 Concentration } \\
(\mathrm{ppm})\end{array}$ & $\begin{array}{c}\text { Germination } \\
\%\end{array}$ \\
\hline 0.1 & $93.5 \pm 1.5^{\mathrm{cd}}$ \\
\hline 0.5 & $96 \pm 1^{\mathrm{bc}}$ \\
\hline 1 & $99 \pm 0^{\mathrm{a}}$ \\
\hline 5 & $97.5 \pm 0.5^{\mathrm{ab}}$ \\
\hline 10 & $91.5 \pm 0.5^{\mathrm{d}}$ \\
\hline
\end{tabular}




\subsection{Rootstock Screenings in Greenhouse}

This study proposes to evaluate the behavior of many commercial tomato rootstocks resistant to soil-borne pathogens provided from international seed-bearers for their resistance to the branched broomrape. Thus, the problems posed are to know if the resistances carried by the rootstocks are effective against the branched broomrape.

The degree of rootstocks susceptibility to $P$. ramosa was estimated by the means of cultures in pots in a soil artificially infested (greenhouse trials were in two consecutive years). After four months of culture, the various parameters were used to measure the resistance of tomato rootstocks to branched broomrape: The total number of attachments, the total number of emerged Phelipanche, the broomrape dry-weight per tomato plant, and the reduction of roots and vegetative part in dry matter of tomato plant in response to the parasitic attack.

\subsubsection{First screening Series}

Concerning the total number of attachment per tomato plant, none of the tomato rootstocks appeared immune to broomrape at 12 weeks after infestation. This number varies from 24 to 171 according to rootstock. Thus, we show that the rootstocks were separated into three different groups according to this parameter (ANOVA, SNK, $\mathrm{P} \leq 0,05, \mathrm{n}=10$ ), with an average number of attachments about of 50 attachments for (Energy with the smallest number, Groundforce, Eldorado, Robusta and Beaufort), about of 120 attachments for (Body, 43965, La4135 and Heman) and about 150 attachments for (La4135, Heman, Brigeor, 42851, Maxifort and Integro with the greatest number), (Figure 2).

The computation of emergences made it possible to distinguish the genotypes little or very favorable to the development of the broomrapes in post-attachment. A small ratio: number of emerged broomrapes / number of fixed broomrapes characterized the little favorable rootstocks. Thus, although all the commercial tomato rootstocks allowed the parasite emergence, three principal groups with a significant difference were showed (ANOVA, SNK, $\mathrm{P} \leq 0,05, \mathrm{n}=10$ ): with an average of 18 emergences for (Robusta, 42851, Body, La4135, Brigeor, Maxifort, Heman and Beaufort), about 15 emergences for (42851, Body, La4135, Brigeor, Maxifort, Heman, Beaufort, Energy and 43965), and about 9 emergences for (Maxifort, Heman, Beaufort, Energy, 43965, Groundforce, Integro and Eldorado), (Figure 2).

Concerning the percentage of emerged broomrapes, three groups of rootstocks were distinguished (ANOVA, SNK, $\mathrm{P} \leq 0,05, \mathrm{n}=10$ ): a first group composed of the rootstocks Robusta (42\%) and Energy (31\%); a second group composed of all the other rootstocks except Integro (13\% on average); and a third group composed only of the rootstock Integro (3\%)

Our results show clearly that the emergence percentage is not correlated with the number of attachments. For example, the rootstocks Eldorado and Robusta carry a similar number of broomrapes but are different very distinctly in the emergences percentage: therefore, contrary to Eldorado, Robusta is very favorable to the development of the broomrapes. An equivalent distinction can be made between Integro and trio Brigeor, Maxifort and 42851. These last three rootstocks are at the same time very sensitive to the broomrape (a high attachments number) and very favorable to the parasite development (a raised emergences percentage). With the difference of Integro, they show a strong capacity to support the growth of a very great number of broomrapes.

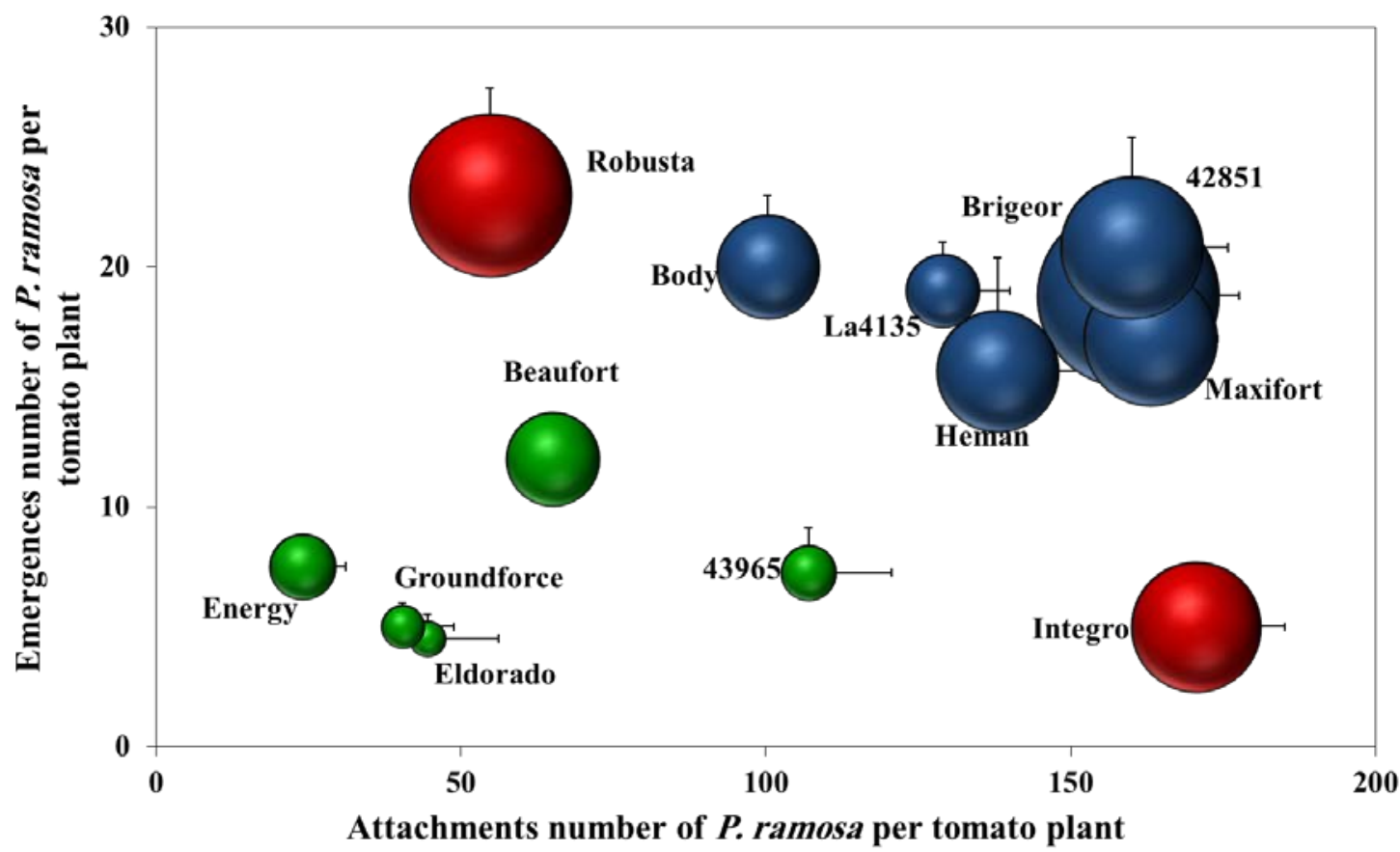

Figure 2. Evaluation of the sensibility to the branched broomrape of different commercial tomato rootstocks. The values are the averages \pm SE (ANOVA, SNK, $\mathrm{P} \leq 0,05, \mathrm{n}=10$ ). Circle size corresponds to the total dry weight of the fixed broomrapes per tomato plant. In green: rootstocks the least susceptible to the broomrape and the least favorable to the development of the parasite. These rootstocks will be revalued at the second stage of screening. In blue: rootstocks the most susceptible to the broomrape and the most favorable to the development of the parasite. These rootstocks will not be revalued at the second screening campaign. In red: rootstocks taken as control for the second screening campaign 
Idem, as in emergence number, for the dry weight of broomrape per tomato plant; there were five considerably different groups, with a dry biomass of broomrapes going from 0,8 g DW in average for (Eldorado and Groundforce with the smallest weight), to 3,4 g DW for (Brigeor and Robusta with the greatest weight), (Figure 2).

Although this first screening did not reveal resistant genotypes to the broomrapes, but it allowed to classify the genotypes considered very susceptible of the genotypes definitely less susceptible to $P$. ramosa. For their interesting characteristics (feeble attachments and emergences number and low total biomass of the broomrapes), the behavior of rootstocks Eldorado, Energy, Groundforce, Beaufort and 43965 was approved to the second stage of screening. It is the same for Robusta and Integro because their very different behavior makes them good controls: Robusta for the high emergences percentage and Integro for the very significant attachments number.

\subsubsection{Second Screening Series}

This revaluation campaign of susceptibility degree of the commercial rootstocks (selected genotypes) is based on the same susceptibility indicators as previously. Moreover, the measurement of the fresh and dry biomass of the roots and aerial parts of the tomato plants will contribute to a finer characterization of the tomato genotypes tested. Realized on control plants not infested, these measurements will also make it possible to evaluate the impact of parasitism on the rootstocks development.

Among the whole of the genotypes tested, the genotype Energy carries less attachment per plant, with an average of 17 broomrapes fixed per tomato plant, including a strong proportion (27\%) emerged out after 4 months of cultures (that is to say 5 emergences). In spite of the reduced number of fixed broomrapes, the dry weight of fixed broomrape on Energy is weak (0.04 g DM/fixed broomrape). The rootstocks Groundforce, Eldorado and Beaufort present a behavior close to that of Energy with a small increase of emergence and attachment number for Beaufort rootstock. The reduced number of fixed and emerged broomrapes for the last genotypes can explain the weak biomass of broomrapes carried by these rootstocks, (Figure 3).

The Integro genotype increases a very significant number of attachments that is to say on average of 150 broomrapes per tomato plant. Only $4 \%$ of the broomrapes emerged after 4 months of culture (that is to say 6 emergences) and the average dry weight of broomrape is relatively weak (0.02 g DM/fixed broomrape). This reflects probably the nutritional competition, which is established between these many fixed broomrapes for the taking away of the nutrients at this very sensitive tomato, (Figure 3).

The Robusta genotype increases a very significant proportion of emergences (42\% emerged out after 4 months of culture that is to say 43 emergences). In spite of the reduced number of fixed broomrapes (43 broomrapes per tomato plant), the average dry weight of a broomrape is relatively immense (0,1 g DM/fixed broomrape). This reflects probably a development accelerated up of the broomrape, which has a great sink strength that competes with the sink organs of this genotype, (Figure 3).

The 43965 rootstock appears very susceptible to the broomrape infestation sight of the very high number of attachment (89 fixed broomrapes per tomato plant) and emergence (16 emergences per tomato plant that is to say $18 \%$ emerged out) and the high average dry weight of fixed broomrapes (1,3g / tomato plant), (Figure 3).

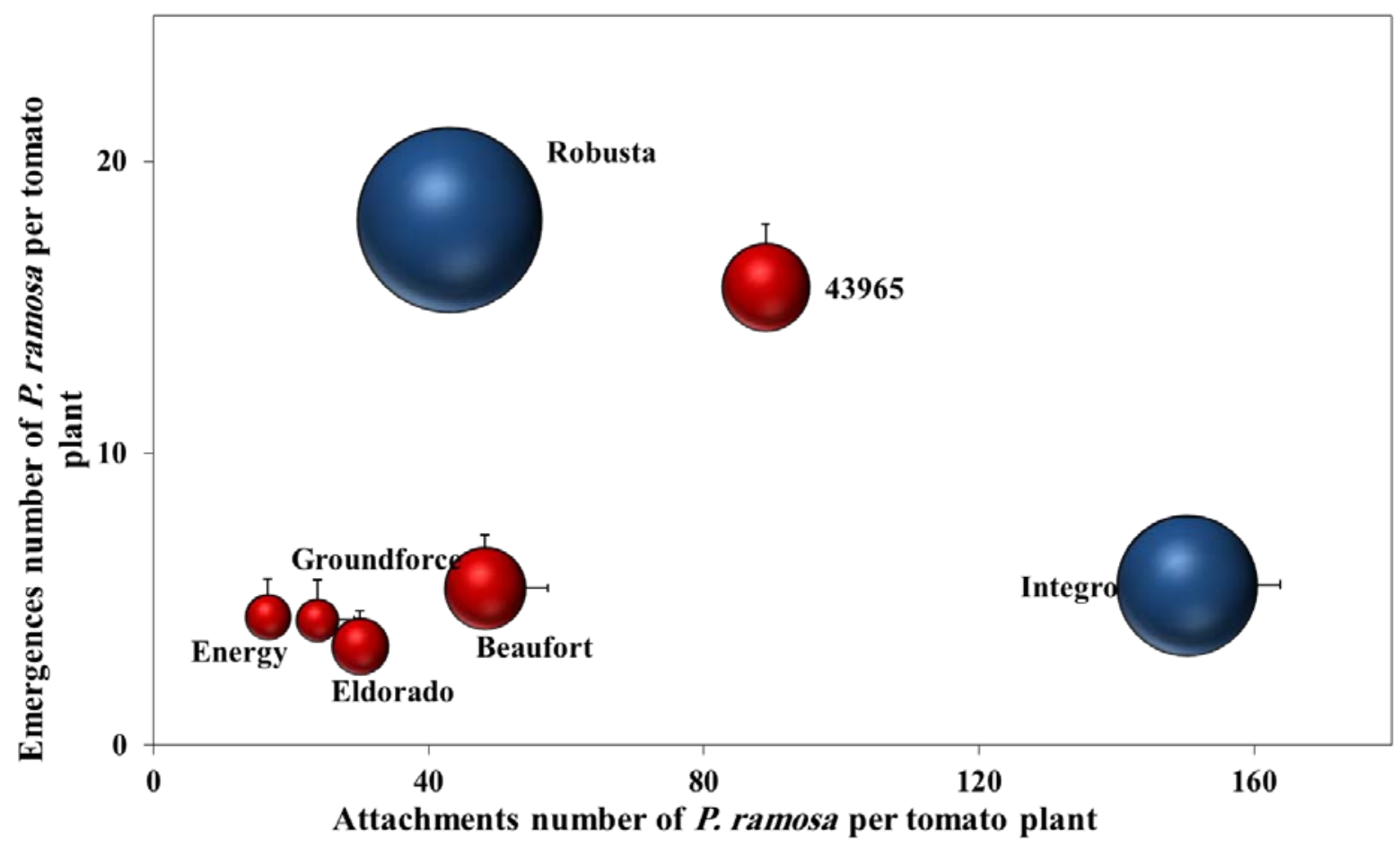

Figure 3. Revaluation of the susceptibility to the branched broomrape of different commercial tomato rootstocks. The values are the averages \pm SE (ANOVA, SNK, $\mathrm{P} \leq 0,05, \mathrm{n}=10$ ). Circle size corresponds to the total dry weight of the fixed broomrapes per tomato plant. In red: the revaluated rootstocks. In blue: the control rootstocks 
In general, the rootstocks susceptibility degree can be given by means of the results of two screening series (Table 3). Only the rootstock 43965 showed a very high number of emergence in second year compared to that in first year (Figure 2 and Figure 3).

\subsection{Influence of the Rootstock Root Biomass on Their Susceptibility Degree to the Broomrape}

With the exception of the most susceptible rootstock, Integro, the root biomass of the rootstocks tends to condition the number of fixed broomrapes (Figure $4, r^{2}=0,7$ ). Thus, these rootstocks present on average 19 fixed broomrapes per g DW of roots $(19,14 \pm 5,95)$. The size of the root system influences at the same time the surface of contact with the parasite and probably the intensity of the stimulants production of broomrape seeds germination. Thus, this result suggests that the lowest sensitivity of Energy is explained by a weaker surface of contact with parasite seeds and/or more limited production of germination stimulants. Concerning Integro, the ratio "number of fixed broomrapes / root biomass" is more important, about 50 fixed broomrapes per g DW of roots. Therefore, this result underlines a fixed broomrapes density on the roots of the Integro rootstock two to three times more raised than that observed on the other rootstocks.

\subsection{Impact of Parasitism on the Rootstocks Development}

The negative impact of parasitism on the total DW of the all rootstocks tested in second screening campaign is presented in Figure 5. It appears that the loss of total DW of a rootstock is positively correlated with the total DW of the fixed broomrapes. Thus, the highest loss of DW is observed for the Integro genotype. In average, $1 \mathrm{~g}$ of broomrape DW causes a loss of $17 \mathrm{~g}$ rootstock DW. These results confirm that the broomrapes act as like as additional seaks on the rootstocks and show that none of the tested rootstocks compensates the diversion of DW by the parasite.

Table 3. Average of the different index of broomrapes sensibility calculated following two screening series. The values are the averages of 20 plants per rootstock. By index, the values carrying the same letter are not significantly different $(\mathrm{ANOVA}, \mathrm{SNK}, \mathrm{P} \leq \mathbf{0 , 0 5}, \mathrm{n}=\mathbf{2 0})$

\begin{tabular}{|l|l|l|l|}
\hline Rootstock & Attachments & Emergences & Broomrapes dry weight (g) \\
\hline Integro & $160,4^{\mathrm{a}}$ & $5,3^{\mathrm{b}}$ & $2,3^{\mathrm{ab}}$ \\
\hline Robusta & $48,9^{\mathrm{de}}$ & $19,0^{\mathrm{a}}$ & $3,0^{\mathrm{a}}$ \\
\hline Beaufort & $56,6^{\mathrm{d}}$ & $8,7^{\mathrm{ab}}$ & $1,6^{\mathrm{bc}}$ \\
\hline Eldorado & $37,3^{\mathrm{de}}$ & $4,0^{\mathrm{b}}$ & $0,8^{\mathrm{c}}$ \\
\hline Energy & $20,3^{\mathrm{e}}$ & $6,0^{\mathrm{b}}$ & $1,0^{\mathrm{c}}$ \\
\hline Groundforce & $32,1^{\mathrm{de}}$ & $4,7^{\mathrm{b}}$ & $0,8^{\mathrm{c}}$ \\
\hline $\mathbf{4 3 9 6 5}$ & $98,0^{\mathrm{c}}$ & $11,6^{\mathrm{ab}}$ & $1,2^{\mathrm{c}}$ \\
\hline
\end{tabular}

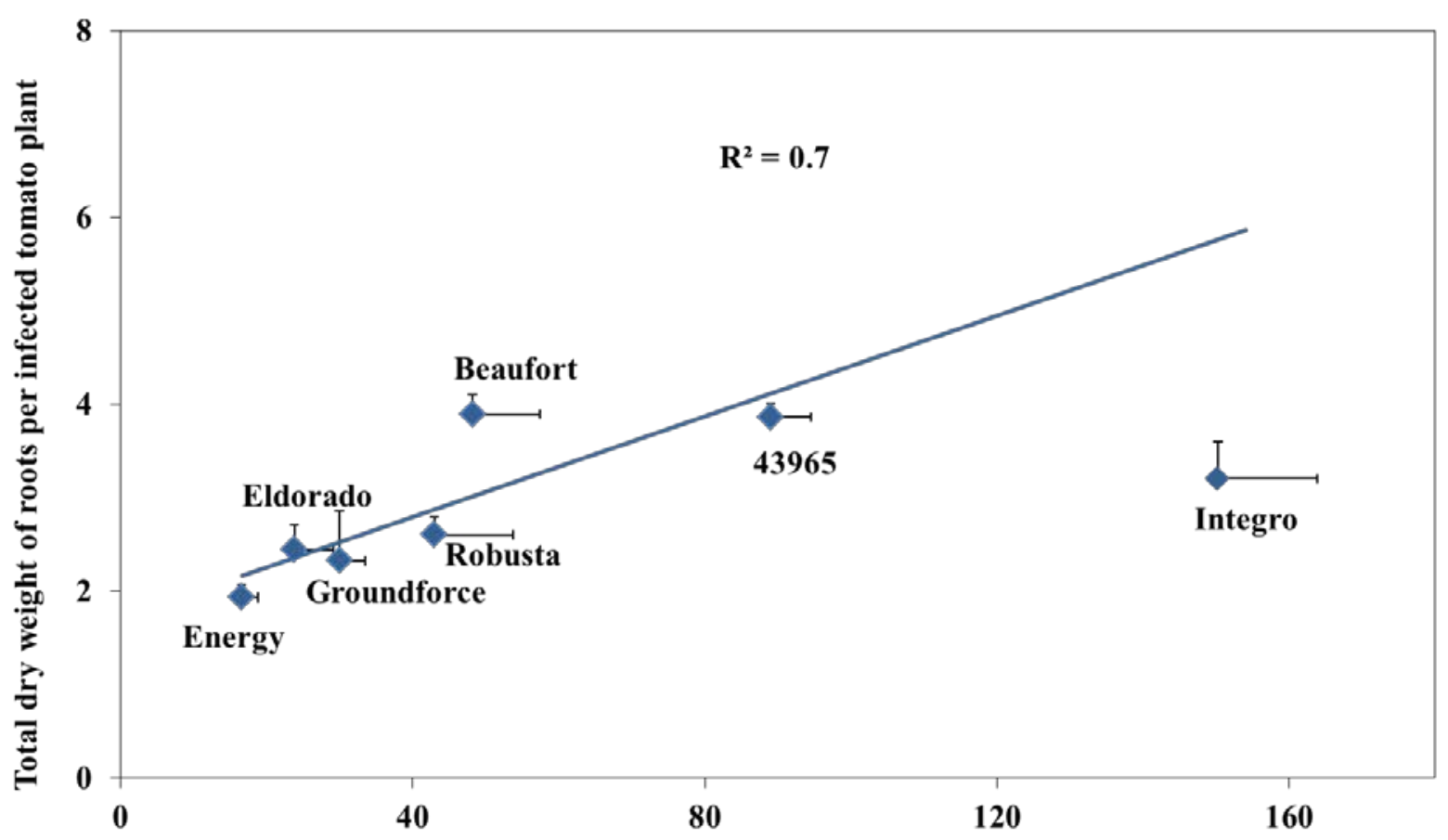

Attachments number per tomato plant

Figure 4. Relation between the total dry weight of tomato rootstock roots and the number of broomrapes fixed per plant. The data correspond to the averages $\pm S E(n=10)$. The correlation is carried out by excluding Integro 


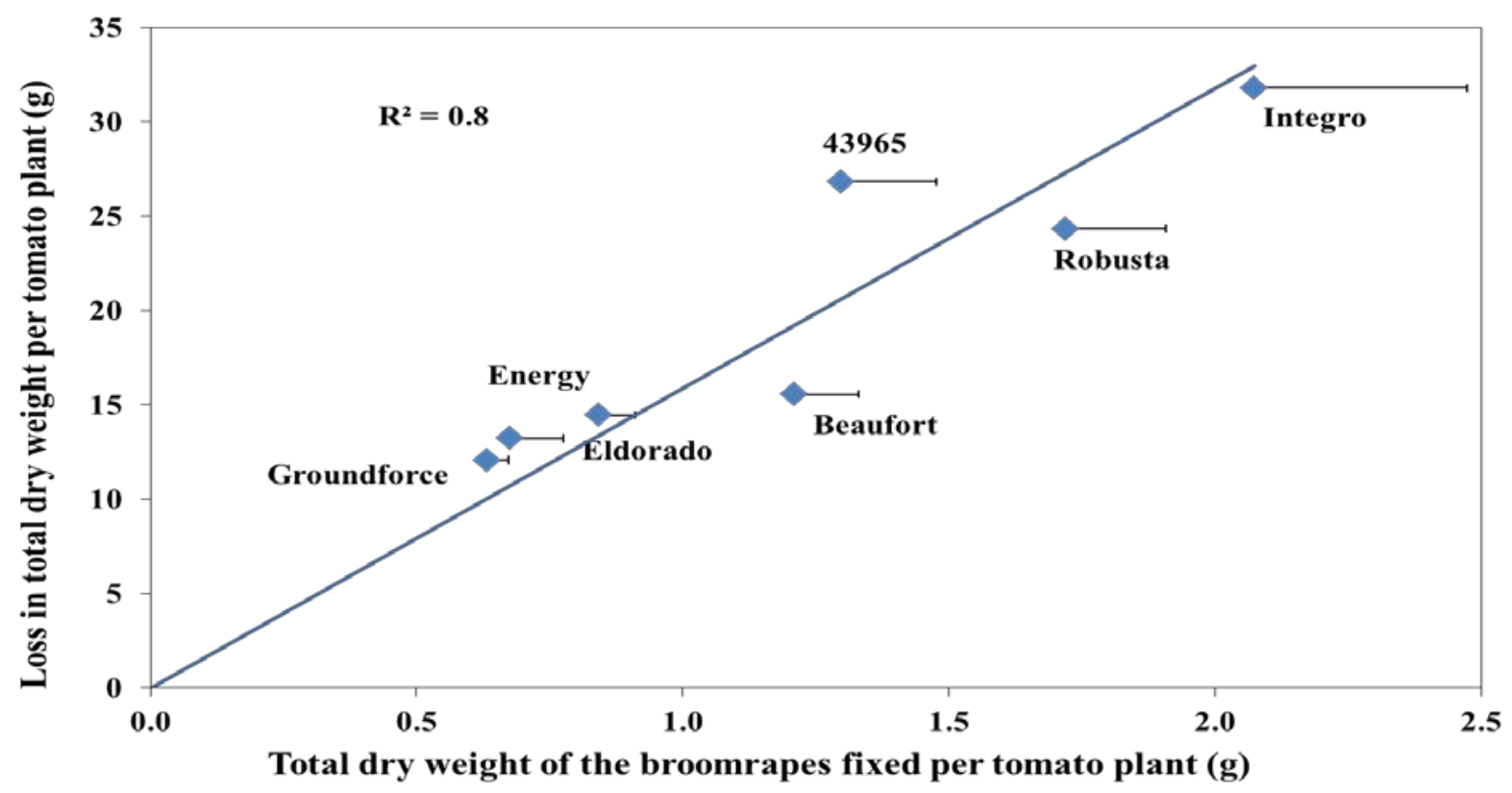

Figure 5. Correlation between the loss in total dry weight of different rootstocks and the total dry weight of the fixed broomrapes. The data correspond to the averages $\pm \mathrm{SE}(\mathrm{n}=10)$

Table 4. Impact of parasitism on the development of different rootstocks. The values are the averages of 10 plants per rootstock. By parameter, the values carrying the same letter are not significantly different (ANOVA, $S N K, P \leq 0,05, n=10$ ). DW: dry weight; R: roots; V: vegetative aerial parts. Control: not infested rootstocks; Test: rootstocks infested by the broomrape

\begin{tabular}{|c|c|c|c|c|c|c|c|}
\hline \multirow{2}{*}{ Rootstock } & \multicolumn{2}{|c|}{ Control } & \multicolumn{2}{|c|}{ Test } & \multicolumn{3}{c|}{ \% Reduction } \\
\cline { 2 - 8 } & DW. R & DW. V & DW. R & DW. V & DW. R & DW. V & Total \\
\hline Integro & $7,8^{\mathrm{a}}$ & $32,40^{\mathrm{ab}}$ & $3,20^{\mathrm{abc}}$ & $5,20^{\mathrm{bcd}}$ & 59 & 84 & 79 \\
\hline Robusta & $5,51^{\mathrm{a}}$ & $24,50^{\mathrm{bc}}$ & $2,60^{\mathrm{bc}}$ & $3,0^{\mathrm{d}}$ & 53 & 87 & 81 \\
\hline Beaufort & $8,69^{\mathrm{a}}$ & $14,83^{\mathrm{c}}$ & $3,89^{\mathrm{ab}}$ & $4,07^{\mathrm{cd}}$ & 55 & 73 & 66 \\
\hline Eldorado & $4,94^{\mathrm{a}}$ & $19,64^{\mathrm{c}}$ & $2,32^{\mathrm{bc}}$ & $7,79^{\mathrm{b}}$ & 53 & 60 & 59 \\
\hline Energy & $4,17^{\mathrm{a}}$ & $17,73^{\mathrm{c}}$ & $1,93^{\mathrm{c}}$ & $6,75^{\mathrm{bcd}}$ & 54 & 62 & 60 \\
\hline Groundforce & $5,1^{\mathrm{a}}$ & $15,11^{\mathrm{c}}$ & $2,44 \mathrm{~b}^{\mathrm{c}}$ & $5,70 \mathrm{~b}^{\mathrm{c}}$ & 52 & 62 & 60 \\
\hline $\mathbf{4 3 9 6 5}$ & $7,5^{\mathrm{a}}$ & $36,32^{\mathrm{a}}$ & $3,86^{\mathrm{ab}}$ & $13,20^{\mathrm{a}}$ & 49 & 64 & 61 \\
\hline
\end{tabular}

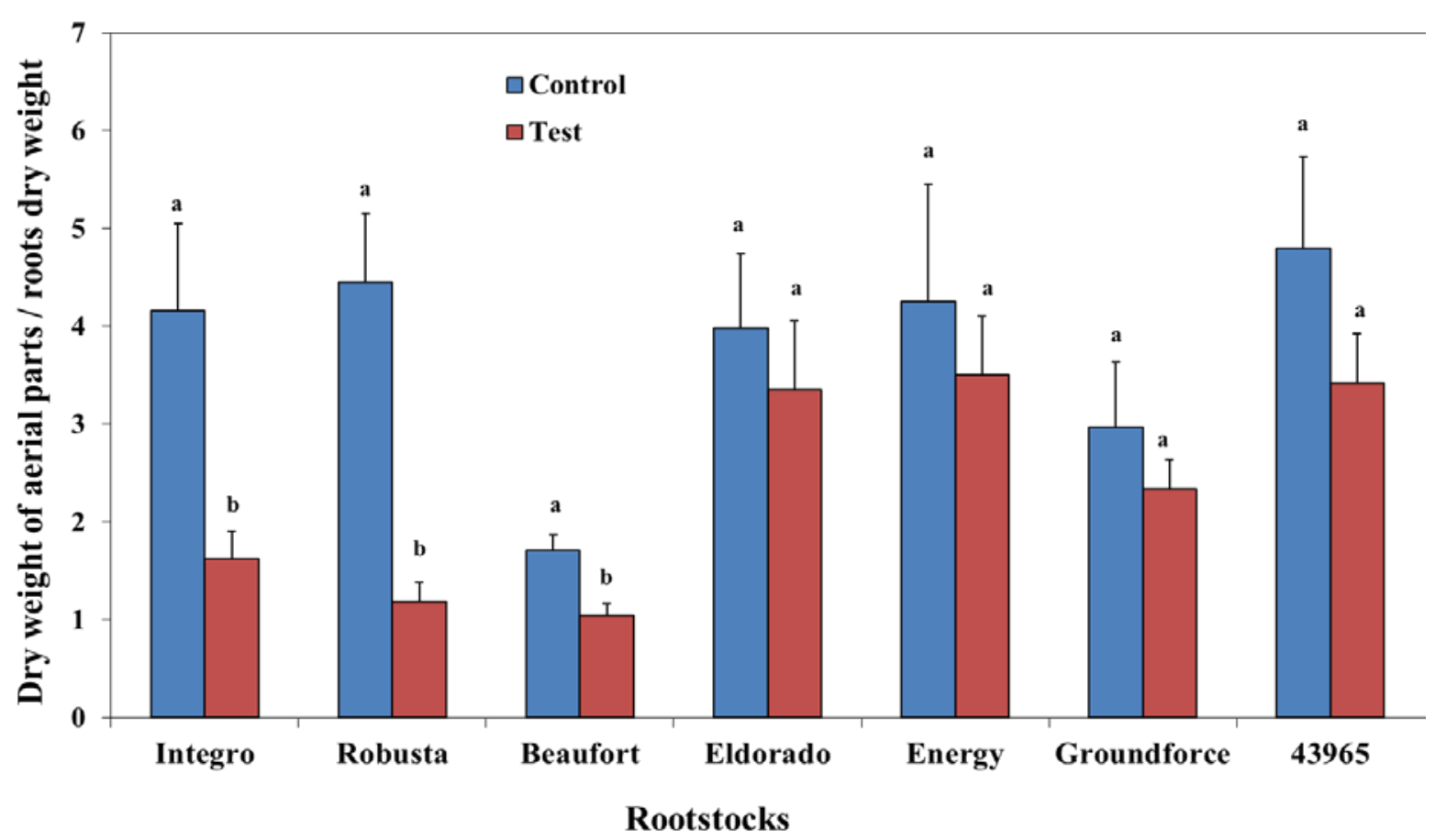

Figure 6. Effect of parasitism on the ratio: dry weight of aerial parts/dry weight of roots of the different rootstocks. Control: not infested rootstocks; Test: rootstocks infested by the broomrape. The values are the averages \pm SE. By rootstock, the values carrying the same letter are not significantly different (ANOVA, SNK, $\mathrm{P}=0,05, \mathrm{n}=10$ ) 
Thus, the total DW of rootstocks is strongly reduced in response to the broomrape. The percentage of total DW reduction varies from $59 \%$ for Eldorado to $81 \%$ for Robusta (Table 4). Whatever the rootstock, the impact of parasitism is stronger on the vegetative aerial-parts development than on that of the root system. Consequently, the infestation affects negatively on the ratio aerial-parts DW / roots DW of the rootstocks (Figure 6), attesting a modification of the plants allometry in consequence of a preferential allowance of the dry matter towards the underground parts. The most significant modifications are observed for Integro and Robusta rootstocks.

\section{Discussion}

This paper shows that there exist among the tomato rootstocks different degrees of sensitivity to the branched broomrape. None of the rootstocks appeared immune to branched broomrape, and they were significantly damaged because the infestation by Phelipanche. No induction of parasitic necrosis after attachment on the host roots was observed, contrary to that described on certain genotypes of sunflower resistant to the O. Cumana [38] and $O$. cernua [47], on certain chickpea and pea genotypes resistant to the $O$. crenata $[48,49]$, on certain fababean genotypes resistant to the $O$. foetida [50], or on tomato genotypes resistant to the $P$. aegyptiaca [27].

We had found two practical techniques of resistance: the first is to control the exudate quantity with which the number of attachment remains low and in consequence the biomass of fixed Phelipanche is too reduced (case of Energy, Groundforce, Eldorado, Beaufort and Robusta rootstocks). According to Perez-de-Luque et al., [51] this type of resistance seems to be based on a less stimulative activity of the root exudates on the parasite seeds whose germination is actually elicited by such molecules [52].

The second method of resistance seems to be rested principally on the limitation of nutrient flows (assimilates) in direction of the fixed broomrapes and on slowing even blocking it at an early stage (case of Energy, Groundforce, Eldorado, 43965 and Integro rootstocks).

In two cases, the plant displays immense sink strength and more than of the parasite. For the suggested reasons, resistance in the genotypes Energy, Eldorado and Groundforce (few fixed and emerged broomrapes) must be underlined and the implied mechanisms in this resistance must be investigated.

This study also showed that the total DW of rootstocks is strongly reduced in response to the broomrape and the impact of parasitism is stronger on the vegetative aerialparts development than on that of the root system. These results join those of Press, [53] and of Barker et al., [54] which underlines the reduction in the photosynthetic capacity and in the ratio aerial-parts DW / roots DW of tomato plants parasitized by the specie $P$. aegyptiaca. Such an impact seems to be a common response to the plants parasitized by the broomrape $[55,56]$. Nevertheless, the degree with which the parasite affects the plant biomass and allometry depends on biotic (genotypes of the host and the parasite plants) and abiotic factors (precocity of the parasitic attacks, conditions of culture.), like that was shown for Striga, another plant parasite epirhize [57,58].

El-Halmouch et al., [27] found that the wild species $S$. pennellii and $S$. hirsutum were resistant to $P$. aegyptiaca and the cultivated tomato genotypes $S$. lycopersicum was a susceptible host. They demonstrated that the susceptible genotypes induce far greater germination of $P$. aegyptiaca seeds than those resistant. Moreover, root exudates of $S$. pennellii inhibited the germination of $P$. aegyptiaca seeds and their use as an irrigation liquid on the susceptible genotypes was a relatively efficient to decrease both the number of tubercles and the biomass of $P$. aegyptiaca while spike emergence was retarded, whereas the inhibition is removed by dilution. Whitney [28] also found that both the extract and exudates from broad bean roots stimulated Orobanche crenata to germinate at low concentrations but less at high concentrations. Brown et al., [59] found that high concentrations of host root exudates were reported to inhibit germination of $O$. minor seeds. Johnson et al., [60] also mentioned that the germination of $P$. ramosa seeds was stimulated by an analogue of strigol at low concentrations but it was inhibited at higher concentrations. Mallet, [61] and Whitney, [28] suggested that root exudates contain both germination stimulants and inhibitors. As well Whitney and Carsten, [29] showed that host root exudates affect the germination of broomrape seeds and also contain inhibitory components that influence the size and direction of growth of the resulting radical. While Gadkar et al., [62] proved this hypothesis in agreement that the root exudate molecules acquired allelopathic effects. However, natural inhibitors from root exudates have not been isolated, whereas natural and chemical analogues of stimulating substances decreased the germination at an optimal concentration $[60,63,64,65]$. Moreover, the germination stimulating capacities is different according to the host plant age, it beings too late at the susceptible genotypes which are suitable to avoid Phelipanche infestation [27]. Shey, [66] mentioned that root exudates of peanut (Arachis hypogaea L.) exhibit qualitative and quantitative changes in their composition with the increasing age of the plant.

The genetic variability of the commercial rootstocks is very significant since the degree of sensitivity determined by the number of fixed broomrapes by tomato plant varies from a factor 1 for Energy to 9 for Integro. Energy is an intraspecific rootstock (hybrid F1, S. lycopersicum $\times S$. lycopersicum). On the other hand, Integro is an interspecific rootstock (hybrid F1, S. lycopersicum $\times S$. hirsutum). The increased sensitivity of this rootstock could come from the relative $S$. hirsutum whose several accessions were shown to be very sensitive to the branched broomrape [36].

Qasem and Kasrawi, [26] discovered that most of Solanaceae crops are susceptible to $P$. ramosa and $P$. aegyptiaca, tomato particularly, and no strong resistance or immunity against either species has been found. This is also confirmed by Foy et al., [24] for 1361 accessions of wild Solanum species screened for their resistance to $P$. aegyptiaca.

To date, the most promising line for its resistance to $P$. ramosa was obtained in Russia (PZU-11) [67], and is used in selection to introduce resistance to the broomrape into 
varieties of tomato intended for the production in the South of Russia [68]. Moreover, this resistance seems ineffective in other areas of production [23].

To increase the genetic variability of tomato, a great number of tomato mutants was also created by mutagenes EMS (ethyl methane sulfanate) then sifted in the field or under artificial infestation for their resistance to the branched broomrape [69]. Thus, some mutants characterized by a number of emergences per tomato plant definitely more reduced than that of the parental lines could be obtained $[69,70]$. The implied mechanisms of resistance are not characterized (or available) to date.

The test of Phelipanche seeds availability showed that all GR24 concentrations produced a completely germination (90-100\%), that can to eliminate the opportunity of infestation possibility. This factor is very important when we evaluate the resistance degree for many genotypes (inter-specific or intra-specific), but in contrary, it reflects the strong viability of broomrape seeds, the parasitic virulence and the quick possibility to break the secondary dormancy.

In another hand, the hybrid type of rootstock haven't any relation with the resistance, while we find a interspecific rootstocks such as Integro and Maxifort which were very susceptible on contrary of the interspecific rootstocks Eldorado, Groundforce which were more resistant or tolerant. The same thing appears in the intra-specific rootstocks, though the rootstock Energy was more resistant contrary to Robusta which was the more susceptible.

\section{Conclusions}

The objective of this work was to estimate the resistance degree of tomato rootstocks, resistant to the majority of soil parasites, to the parasitic weed branched Broomrape and to approximate the impact level of $P$. ramosa on the dry weight of this highly infected rootstocks. The present study is the first report on rootstocks resistance to $P$. ramosa including genotypes selected for their resistance to the soil parasite.

This study did not reveal any source of resistance and tolerance to the branched broomrape among the many rootstocks tested. All the genotypes tested are sensitive and show a consequent loss of biomass under infestation. It thus invalidates the assumption of a possible transfer of a resistance to the telluric parasites for the broomrape. Thus, the genes of resistance to different telluric pathogens carried by the majority from the tested rootstocks are not assets for the acquisition of resistance to the branched broomrape.

This study also showed that: the degree of rootstocks sensitivity is conditioned by its root biomass; the loss of total DW of a rootstock is definitely correlated with the total DW of the attached broomrapes and the impact of parasitism was more concentrated on the vegetative parts.

Energy, Groundforce and Eldorado were less sensitive to branched broomrape and they gave the best results among the tested rootstocks (few fixed and emerged broomrapes and smallest biomass of total broomrapes).

We wish now to determine the influence of the grafting on the resistance degree of selected genotypes. Indeed, a graft with "strong vegetative growth and strong productivity" could represent "a major competitive sink" against to the fixed broomrapes and thus unbalance the division of assimilates between the vegetative part of the grafted plant and the broomrapes, in favorite of the tomato plant.

\section{Acknowledgements}

The author thanks Prof. Philippe SIMIER and Dr. Séverine THOIRON for allowing the research to be conducted in the LBPV laboratory; the Rootstocks Furnishers Societies (De Ruiter seeds, Enzazaden Gautier, and Vilmorin); Dr. H. Benharrat for the broomrape seeds and D. Bozec and J. Schmidt for technical assistance.

\section{References}

[1] Hodosy (1981). Biological control of broomrape, Orobanche ramosa, a tomato parasite. In: Occurrence and Adaptability of Fusarium species to Control Broomrape in Hungary, Zoldsegtermesztesi, Kutato Intezet Bulletinje 14: 21-29.

[2] Fracchiolla, Boari (2000). Effetti dell'infestazione di Orobanche ramosa sulla produzione di pomodoro ecavolfiore. Informatore Fitopatologico 2: 52-54

[3] Tóth P, Cagán L (2003). A decrease in tomato yield caused by branched broomrape (Orobanche ramosa) parasitization. Acta Fytotechnica et Zootechnica 6(3): 65-68.

[4] Mauromicale G, Monaco AL, Longo AMG (2008). Effect of Branched Broomrape (Orobanche ramosa) Infection on the Growth and Photosynthesis of Tomato. Weed Science 56: 574-581.

[5] Cubero JI (1983). Parasitic diseases in Vicia faba. With special reference to broomrape (Orobanche crenata Forsk.). In: Hebblethwaite P.D. (ed.), The faba bean (Vicia faba) a basis for improvement. Butterworth, London: 493-521.

[6] Gressel J, Hanafib A, Headc G, Marasasd W, Obilanae AB, Ochandaf JS, T, Tzotzosh G (2004). Major heretofore intractable biotic constraints to African food security that may be amenable to novel biotechnological solutions. Crop Protection 23: 661-689.

[7] Parker C, Riches CR (1993). Parasitic weeds of the world: Biology and control. CAB International, Wallingford, UK: 332p.

[8] Barcinsky R (1934). C.R. Acad. Sci. U.R.S.S 1: 343.

[9] Chabrolin C (1934). C.R. Acad. Sci., Pari8 198: 2275.

[10] Joel DM, Steffens JC, Matthews DE (1995). Germination of weedy root parasites. In: Kigel J, Galili G, eds. Seed development and germination. New York: Marcel Dekker, Inc: 567-598.

[11] Zemrag A (1999). L’orobanche. monographie et gestion dans les cultures des légumes alimentaires. Transfert de technologie en agriculture. PNTTA 63: 1-4.

[12] Montemurro P, Fracchiolla M, Caramia D (2006). In vitro experiments on the control of Orobanche ramosa L. with glyphosate in tomato. Workshop Parasitic Plant Management in Sustainable Agriculture. Final meeting of COST849. ITQB Oeiras-Lisbon Portugal: 40.

[13] Abu-Irmaileh, B.E. 1991a. Weed control in squash and tomato fields by soil solarization in the Jordan Valley. Weed Res. 31(3): 125-133.

[14] Abu-Irmaileh, B.E. 1991b. Soil solarization controls broomrapes (Orobanche spp.) in host vegetable crops in the Jordan Valley. Weed Tech. 5: 575-581.

[15] Amsellem Z, Barghouthi S, Cohen B, Goldwasser Y, Gressel J, Hornok L, Kerenyi Z, Kleifeld Y, Klein O, Kroschel J, Sauerborn J, Müller-Stöver D, Thomas H, Vurro M, Zonno M-C. (2001). Recent advances in the biocontrol of Orobanche (broomrape) species. BioControl 46(2): 211-228.

[16] Boari A, Vurro M. (2004). Evaluation of Fusarium spp. and other fungi as biological control agents of broomrape (Orobanche ramosa). Biological Control 30: 212-219.

[17] Hershenhorn J, Plakhine D, Goldwasser Y, Westwood JH, Foy CL, Kleifeld Y. (1998). Effect of sulfonylurea herbicides on early development of Egyptian brommrape (Orobanche aegyptiaca) in tomato (Lycopersicon esculentum). Weed Technology 12: 108-114. 
[18] Eizenberg H, Hershenhorn J, Graph S, Manor H. (2003) Orobanche aegyptiaca control in tomato with sulfonylurea herbicides. Acta Hort. (ISHS) 613: 205-208.

[19] Lopez-Pérez JA, Le Strange M, Kaloshian I, Ploeg AT. (2006). Differential response of $\mathrm{Mi}$ gene-resistant tomato rootstocksto root-knot nematodes (Meloidogyne incognita). Crop Protection 25: 382-388.

[20] Lejeune A, Constant S, Delavault P, Simier P, Thalouarn P, Thoiron S. (2006). Involvement of a putative Lycopersicon esculentum wall-associated kinase in the early steps of tomatoOrobanche ramosa interaction. Physiological and Molecular Plant Pathology 69: 3-12.

[21] Dalela GG, Mathur RL. (1971). Resistance of varieties of eggplant, tomato and tobacco to broomrape (Orobanche cernua Loef.). Pest Articles and News Summaries 17: 482-483.

[22] Abu-Gharbieh WI, Makkouk KM, Saghir AR. (1978). Response of different tomatocultivars to the root-knot nematode, tomatoyellow leaf curl virus, and Orobanche inJordan. Plant Dis. Repoter 62(3): 263-266.

[23] Foy CL, Jacobsohn R, Jain R. (1987). Evaluation of tomato lines for resistance to glyphosate and/or Orobanche aegyptiaca. Pers. In: Parasitic Flowering Plants Proceeding of the 4th ISPFP (eds HC Weber \& W Forstreuter). Marburg Germany: 221-230.

[24] Foy CL, Jacobsohn R, Jain R. (1988) Screening of Lycopersicon spp. for glyphosate and/or Orobanche aegyptiaca Pers. resistance. Weed research 28(5): 383-391.

[25] Kasrawi MA, Abu-Irmaileh BE. (1989). Resistance to branched broomrape (Orobanche ramosa) in tomato germplasm. HortScience 24(5): 822-824.

[26] Qasem JR, Kasrawi MA. (1995). Variation of resistance to broomrape (Orobanche ramosa) in tomatoes. Euphytica 81: 109-114.

[27] El-Halmouch Y, Benharrat H, Thalouarn P. (2006). Effect of root exudates from different tomato genotypes on broomrape (O. aegyptiaca) seed germination and tubercle development. Crop Protection 25: 501-507.

[28] Whitney PJ. (1978). Broomrape (Orobanche) seed germination inhibitors from plant roots. Annals of Applied Biology 89: 475-478.

[29] Whitney PJ, Carsten C. (1981). Chemotropic response of broomrape radicals to host root exudates. Ann. Bot 48: 919-921.

[30] Miller JC, Tanksley SD (1990). RFLP analysis of phylogenetic relationships and genetic variation in the genus Lycopersicon. Theoretical and Applied Genetics 80: 437-448.

[31] Causse M, Caranta C, Saliba-Colombani V, Moretti A, Damidaux R, Rousselle P. (2000). Valorisation des ressources génétiques de la tomate par l'utilisation de marqueurs moléculaires. Ressources génétiques : Cahiers Agricultures 9(3): 197-210.

[32] Lambert L, Fortin R, Ouellet C. (2003). Le greffage de la tomate (Cultures en serres). Réseau d'Avertissements Phytosanitaires. Bulletin d'information 4: 6p.

[33] Besri M. (2002). Alternatives to Methyl Bromide for tomato production in the Mediterranean area. Proceedings of International Conference on Alternatives to methyl Bromide. Seville Spain: 162-166.

[34] Besri M. (2003). Tomato grafting as an alternative to Methyl Bromide in Morocco. Proceedings of the international research conference on methyl bromide alternatives and emissions reductions. San Diego California: 12.

[35] Vitre A. (2002). Le greffage des tomates. Rapport technique: 4p.

[36] El-Halmouch YH. (2004). Recherche de mécanismes de résistance à l'Orobanche chez des génotypes de tomate ; Aspects histologiques, physiologiques, moléculaires et génétiques Thèse de Doctorat Université de Nantes: 328.

[37] Coïc Y, Lesaint C. (1975). La nutrition minérale et en eau des plantes en horticulture avancée. Le Document Technique de la SCPA 23: 1-22.

[38] Labrousse P, Arnaud MC, Serieys H, Berville A, Thalouarn P (2001). Several mechanisms are involved in resistance of Helianthus to Orobanche cumana Wallr. Ann. Bot 88: 859-868.

[39] Sillero JC, Rubiales D, Cubero JI. (1996). Risk of Orobanche resistance screening based only on number of emerged shoots per plant. In: Moreno M.T., J.I. Cubero, D. Berner, D. Joel, L.J. Musselman and C. Parker (eds.), Advances in parasitic plant research. Proceedings of the 6th International on parasitic weed symposium, Cordoba Espagne: 929p.
[40] Gil J, Martin LM, Cubero JI. (1984). Resistance to Orobanche crenata Forsk. in Vicia sativa L. II. In: Parker C.L., L.J. Musselman, R.M. Polhill and A.K. Wilson (eds.). Proceedings of the Third International Symposium on ParasiticWeeds, ICARDA Aleppo: 221-229.

[41] Gil J, Martın LM, Cubero JI. (1987). Genetics of resistance in V. sativa to O. crenata Forsk. Plant Breed 99: 134-143.

[42] Cubero JI. (1991). Breeding for resistance to Orobanche species: a review In: Wegmann K. and L.J. Musselman (eds.). Progress in Orobanche research Proceedings of the international Workshop on Orobanche research. Obermarchtal Allemagne: 257-277.

[43] Snelder Y, Moreno MT, Martin A, Gil J. (1994). Screening for resistance to Orobanche crenata Forsk in Vicia faba L. In: Pieterse A.H., J.A.C. Verkleij and S.J.ter Borg (eds.), Biology and management of Orobanche. . Proceeding of the 3rd International Workshop on Orobanche and related Striga research, Amsterdam Pays-Bas: 474-481.

[44] Sillero JC, Moreno MT, Rubiales D. (1996). reliminary Screening for Broomrape (Orobanche crenata) resistance in Vicia species. In: Moreno M.T., J.I. Cubero, D. Berner, D. Joel, L.J. Musselman and C. Parker (eds.), Advances in parasitic plant research. Proceedings of the 6th International on parasitic weed symposium, Cordoba Espagne: 929p.

[45] Abbes Z (2007). Estimation de la sensibilité et de la tolérance de différents génotypes de féverole (Vicia faba L.) à la plante parasite Orobanche foetida Poiret. Impact du génotype hôte sur les particularités physiologiques et métaboliques du parasite. Thèse de Doctorat Université de Nantes: 155p.

[46] Draie R. (2009). Effet du greffage sur la productivité de la tomate en conditions de non infestation et d'infestation par l'orobanche. Caractérisation d'une invertase acide, enzyme majeure de la force de puits du parasite. Thèse de Doctorat, Université de Nantes: 191p.

[47] Serghini K, Perez-de-Luque A, Castejon-Munoz M, Garcia-Torres L, Jorrin JV. (2001). Sunflower (Helianthus annuus L.) response to broomrape (Orobanche cernua Loefl.) parasitism: induced synthesis and excretion of 7-hydroxylated simple coumarins. J Exp Bot 52: 2227-2234.

[48] Rubiales D, Perez-de-Luque A, Cubero JI, Sillero JC. (2003). Crenate broomrape (Orobanche crenata) infection in field pea cultivars. Crop Protection 22: 865-872.

[49] Mabrouk Y, Zourgui L, Sifi B, Delavault P, Simier P, Belhadj O (2007). Some compatible Rhizobium leguminosarum strains in peas decrease infections when parasitised by Orobanche crenata. Weed Research 47: 44-53.

[50] Abbes Z, Kharrat M, Delavault P, Simier P, Chaïbi W (2007). Field evaluation of the resistance of some faba bean (Vicia faba L.) genotypes to the parasitic weed Orobanche foetida Poiret. Crop Protection 26: 1777-1784.

[51] Perez-de-Luque A, Jorrin J, Cubero JI, Rubiales D. (2005). Orobanche crenata resistance and avoidance in pea (Pisum spp.) operate at different developmental stages of the parasite. Weed Res. 45: 379-387.

[52] Zhou WJ, Yoneyama K, Takeuchi Y, Iso S, Rungmekarat S, Chae SH, Sato D, Joel DM. (2004). In vitro infection of host roots by differentiated calli of the parasitic plant Orobanche. J Exp Bot 55: 899-907.

[53] Press MC (1995). How do the parasitic weeds Striga and Orobanche influence host carbon relations? Aspects of Applied Biology 42: 63-70.

[54] Barker ER, Press MC, Scholes JD, Quick WP. (1996). Interactions between the parasitic angiosperm Orobanche aegyptiaca and its tomato host: growth and biomass allocation. New Phytologist 133: 637-642.

[55] Kropff M.J. and Schippers P. (1986). Simulation of the growth of faba beans (Vicia faba L.) infested with broomrapes (Orobanche crenata Forsk.). Proceedings of a workshop on biology and control of Orobanche. LH/VPO, Wageningen, The Netherlands. pp: 2-10.

[56] Graves JD. (1995). Host-plant responses to parasitism. In: Press MC, Graves JD (eds). Parasitic plants. London: Chapman and Hall: 206-225.

[57] Pieterse AH, Verkleij JAC. (1991). Effect of soil conditions on Striga development - a review. In: Ransom, JK, Musselman, LJ, Worsham AD, Parker, C (eds.). Proceedings of the 5th International Symposium of Parasitic Weeds. International Maize and Wheat Improvement centre (CIMMYT) Nairobi: 329-339. 
[58] Cechin I, Press MC. (1993). Nitrogen relations of the sorghumStriga hermonthica host-parasite association: growth and photosynthesis. Plant, Cell \& Environment 16: 237-247.

[59] Brown R, Greenwood AD, Johnson AW, Long AG (1951). The stimulant involved in the germination of Orobanche minor Sm. I. Assay technique and bulk preparation of the stimulant. Biochem $\mathrm{J}$ 48: 559-564.

[60] Johnson AW, Rosebery G, Parker C (1976). A novel approach to Striga and Orobanche control using synthetic germination stimulants. Weed Research 16: 223-227.

[61] Mallet AI. (1973). Studies in the chemistry of Orobanche crenata germination factors present in the roots of Vicia faba and other hosts. Proc. Eur. Weed Res. Sympos Parasitic Weeds: 89-98.

[62] Gadkar V, David-Schwartz R, Nagahashi G, Douds DD, Wininger S, Kapulnik Y. (2003). Root exudate of pmi tomato mutant M161 reduces AM fungal proliferation in vitro. FEMS Microbiology Letters 223: 193-198.

[63] Zahran MK. (1982). Control of parasitic plants (broomrape and dodder) in different crops in Egypt. Agricultural Research Program. Final Technical Report PL 480. Agricultural Research Centre Cairo: 52p.

[64] Saghir AR. (1986). Dormancy and germination of Orobanche seeds in relation to control methods. In S.J. ter Borg (ed.). Biology and Control of Orobanche. Landbouwhoge school, wageningen Netherlands: 25-34.
[65] Stewart GR, Press MC. (1990). The physiology and biochemistry of parasitic angiosperms. Ann. Rev. Plant Physiol. Plant Mol. Biol 41: 127-151.

[66] Shey FJ (1971). The effect of low levels of calcium on exudation of sugars from peanut roots under xenobiotic conditions. Ph.D. Thesis, Virginia Polytechnic Institute and State University Blacksburg VA 24061.

[67] Avdeyev YI, Scherbinin BM. (1977). Tomato resistant to broomrape, Orobanche aegyptiaca. Report of the Tomato Genetics Cooperative, Department of Vegetative Crops, University of California Davis, Report No. 27.

[68] Avdeyev YI, Scherbinin BM, Ivanova LM, Avdeyev AY. (2003). Studying of tomato resistance to broomrape and breeding varieties for processing. Acta Horticulturae (ISHS) 613: 283-290.

[69] Kostov K, Batchvarova R, Slavov S. (2007). Application of chemical mutagenesis to increase the resistance of tomato to Orobanche ramosa L. Bulgarian Journal of Agricultural Science 13: 505-513.

[70] Hershenhorn J (2006). Integrated broomrape control: sanitation, resistant lines, chemical and biological control—can we combine them together? In: Final COST 849 Meeting, State of the Art Lecture in Workshop on Parasitic Plant Management in Sustainable Agriculture, Oeiras-Lisbon Portugal. 